\title{
Saponins as Modulators of the Blood Coagulation System and Perspectives Regarding Their Use in the Prevention of Venous Thromboembolic Incidents
}

\author{
Beata Olas ${ }^{1, * \mathbb{C}}$, Karina Urbańska ${ }^{2}$ and Magdalena Bryś ${ }^{3}$ \\ 1 Department of General Biochemistry, Faculty of Biology and Environmental Protection, University of Lodz, \\ Pomorska 141/3, 90-236 Lodz, Poland \\ 2 Faculty of Medicine, Medical University of Lodz, 90-419 Lodz, Poland; karina.urbanska@stud.umed.lodz.pl \\ 3 Department of Cytobiochemistry, Faculty of Biology and Environmental Protection, University of Lodz, \\ Pomorska 141/3, 90-236 Lodz, Poland; magdalena.brys@biol.uni.lodz.pl \\ * Correspondence: beata.olas@biol.uni.lodz.pl; Tel./Fax: +48-42-6354485
}

Received: 3 October 2020; Accepted: 4 November 2020; Published: 6 November 2020

\begin{abstract}
Saponins comprise a heterogenous group of chemical compounds containing a triterpene or steroid aglycone group and at least one sugar chain. They exist as secondary metabolites, occurring frequently in dicotyledonous plants and lower marine animals. Plant saponin extracts or single saponins have indicated antiplatelet and anticoagulant activity. Venous thromboembolism (VTE), including deep venous thrombosis and pulmonary embolism, is a multifactorial disease influenced by various patient characteristics such as age, immobility, previous thromboembolism and inherited thrombophilia. This mini-review (1) evaluates the current literature on saponins as modulators of the coagulation system, (2) discusses the impact of chemical structure on the modulation of the coagulation system, which may further provide a basis for drug or supplement design, (3) examines perspectives of their use in the prevention of VTE. It also describes the molecular mechanisms of action of the saponins involved in the prevention of VTE.
\end{abstract}

Keywords: saponins; thromboembolic incidents; antiplatelet activity; antithrombotic effect; anticoagulation

\section{Introduction}

A number of plants produce saponins as secondary metabolites. They are particularly common in families such as the Araliaceae, Leguminosae, Polygalaceae, Campanulaceae, Dioscoreaceae, Liliaceae, and Scrophulariaceae [1,2]. Many of these plants have long been used in alternative medicine, such as Panax notoginseng (Burkill) F.H.Chen, Bupleurum chinense DC., Paris polyphylla Sm., and Dioscorea polystachya Turcz. in Chinese medicine. However, specialized research equipment is needed to accurately determine the composition of these plants and study the pharmacological action of individual chemical compounds [3,4].

It is difficult to incorporate the saponins present in terrestrial plants, and some marine organisms, in modern pharmaceuticals. The saponin content in plants depends on many factors, including the plant species and organ, as well as environmental factors and post-harvest treatments. Individual plant species usually contain a mixture of many saponins with a wide variety of chemical and biological properties $[5,6]$.

Saponins are amphipathic glycosides that exhibit foaming properties. Structurally, they consist of a lipophilic polycyclic aglycone, termed a sapogenin, attached to one or more sugar side chains. Figure 1 contains a diagram showing the structure of saponins and their potential properties for preventing thromboembolic events [7-9]. 


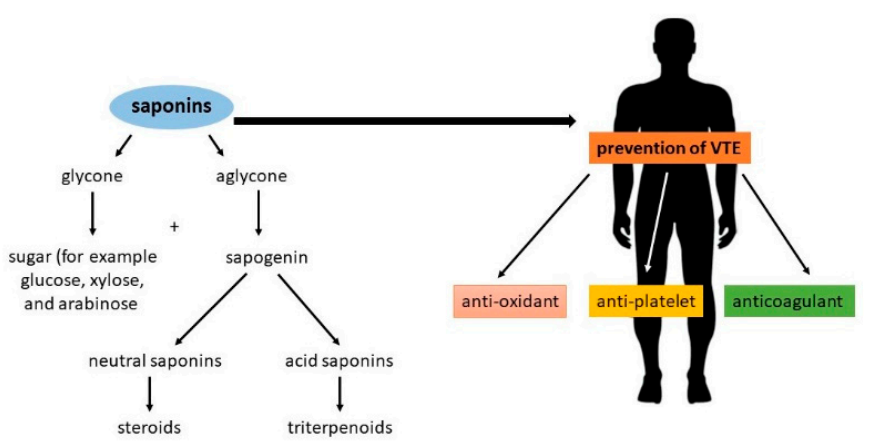

Figure 1. The structure of saponins and their potential properties in the prevention of venous thromboembolism $[8,9]$.

Saponins have been attributed to various health benefits, including cholesterol reduction, antioxidant activity, and cancer risk reduction. For example, cardioprotective properties, including anti-atherosclerotic properties of 20(S)-protopanaxadiol saponins, have been observed in ApoE-deficient mice [10]. It has been found that the administration of saponins isolated from leaves of Panax quinquefolius L. (125 and $250 \mathrm{mg} / \mathrm{kg}$ daily, for 15 days) influences cisplatin-induced cardiotoxicity, in part by inhibition of nuclear factor kappa-light-chain-enhancer of activated B cells (NF- $\kappa B$ ) activity and regulation of the phosphoinositide 3-kinase (PI3K)/protein kinase B (Akt)/apoptosis mediated signaling pathway. The tested saponins also reduced the level of cisplatin-induced oxidative stress in mice, as determined by reactive oxygen species concentration, glutathione level and superoxide dismutase activity [11]. Similar properties have been observed for a steroidal saponin extract from Ophiopogon japonicus (Thunb.) Ker Gawl. root: This extract was shown to alleviate chronic doxorubicin-induced heart failure in an animal model by inhibiting oxidative stress [12]. Sun et al. and Dong et al. also report Panax notoginseng saponins to demonstrate antioxidative activity $[13,14]$. However, the chemical structure, and hence the properties of saponins, have been found to change during storage, and under other conditions [7].

Venous thromboembolism (VTE), including deep venous thrombosis and pulmonary embolism, is a multifactorial disease whose occurrence is strongly influenced by characteristics such as patient age, immobility, previous thromboembolism and inherited thrombophilia. Other risk factors for VTE include obesity, hospitalization for surgery, active cancer, confinement in a nursing home, immobility or leg paresis, oral contraception and hormone therapy, among others. Moreover, VTE is categorized by the U.S. Surgeon General as a major public health problem $[15,16]$.

This mini-review evaluates the current literature on saponins as modulators of the coagulation system, and perspectives regarding their use in the prevention of VTE. It also describes the mechanisms of action of saponins involved in the prevention of VTE.

\section{Saponins with Antiplatelet and Anticoagulation Activity}

Studies on the presence of antiplatelet and anticoagulant compounds in plants began in the 1980s. It has since been found that a variety of groups of chemical compounds are responsible for this anti-platelet activity, with terpenoids and flavonoids being the main class of active compounds in over $30 \%$ of studied plants, followed by saponins, phenylpropanoids, coumarins and various others [17]. Later published research on antiplatelet and anticoagulant activity has been performed with both the use of plant extracts and/or pure compounds [3,11,18,19].

Some studies report the pharmacological properties of single and specific saponins with antithrombotic, anti-platelet aggregation and anticoagulation effects [20-23]. Table 1 summarizes the results of recent in vitro and in vivo studies, based on various models, on the antiplatelet and antithrombotic activity of individual saponins. For example, some saponins have an effect on the coagulation cascade, including prothrombin and other coagulation factors $[18,23]$. 
Table 1. Steroidal and triterpenoid saponins with antiplatelet and antithrombotic activity (in vitro and in vivo models).

\begin{tabular}{|c|c|c|c|c|}
\hline $\begin{array}{l}\text { No and Compound Name, } \\
\text { Concentration Used }\end{array}$ & Model & Property & Chemical Structure & Reference \\
\hline & \multicolumn{4}{|c|}{ Steroidal saponins } \\
\hline $\begin{array}{l}\text { (1) Anemarrhenasaponin } A_{2} \\
\text { (50 and } 100 \mu \mathrm{g} / \mathrm{mL})\end{array}$ & Male Wistar rats (PRP) & $\begin{array}{l}\text { Inhibitory effects on } \\
\text { ADP-induced platelet } \\
\text { aggregation }\end{array}$ & & {$[24]$} \\
\hline (2) Anemarsaponin B & $\begin{array}{l}\text { Male Wistar rats (PRP and } \\
\text { washed blood platelets) }\end{array}$ & $\begin{array}{l}\text { Inhibitory effects on } \\
\text { ADP-induced platelet } \\
\text { aggregation; delayed } \\
\text { thromboplastin time }\end{array}$ & & [20] \\
\hline
\end{tabular}


Table 1. Cont.

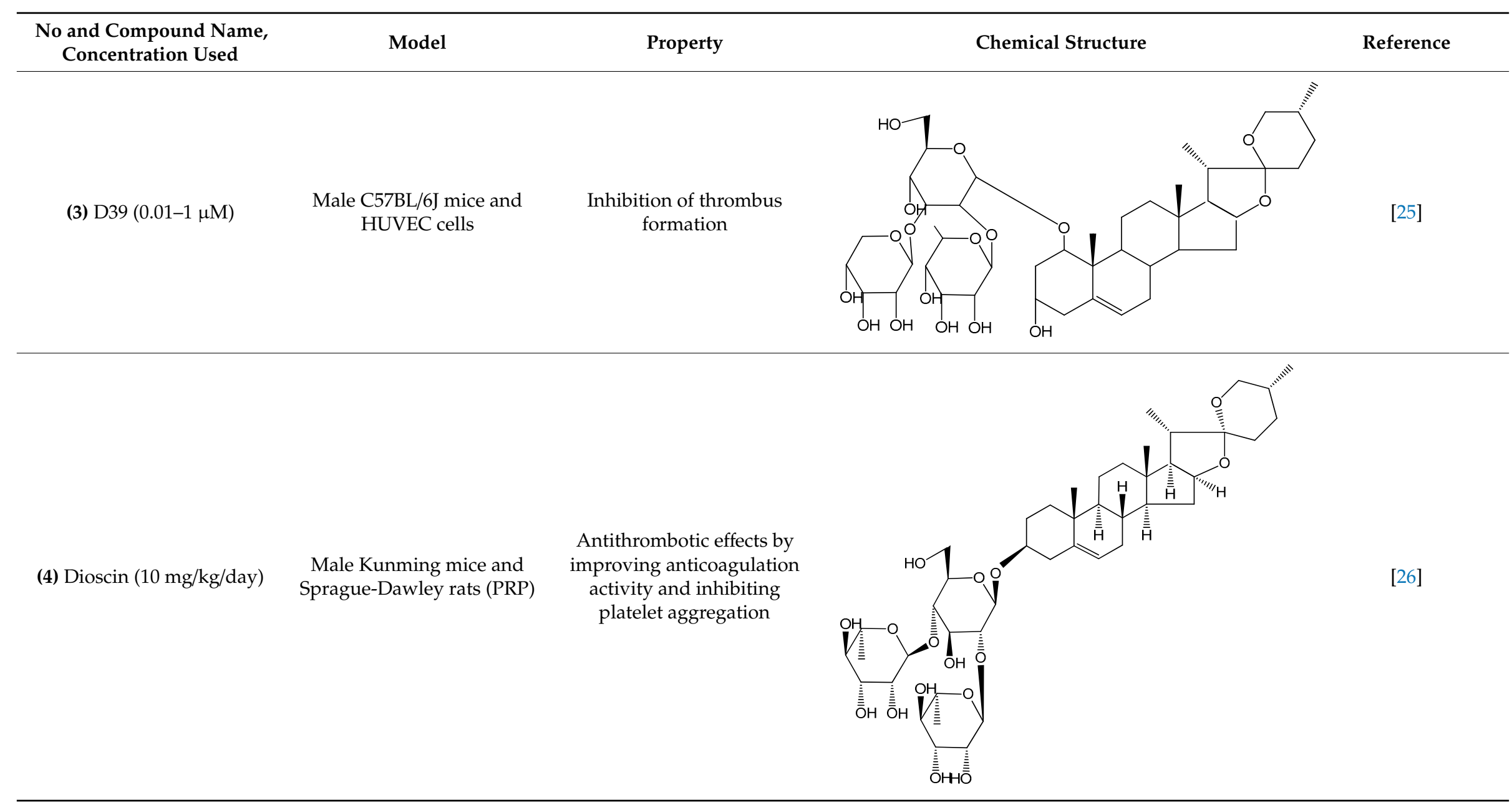


Table 1. Cont.

\begin{tabular}{|c|c|c|c|c|}
\hline $\begin{array}{l}\text { No and Compound Name, } \\
\text { Concentration Used }\end{array}$ & Model & Property & Chemical Structure & Reference \\
\hline $\begin{array}{c}\text { (5) Diosgenyl } \\
\beta \text {-D-galactopyranosyl- }(1 \rightarrow 4)- \\
\beta \text {-D-glucopyranoside }(25-100 \mu \mathrm{M})\end{array}$ & Male Wistar rats (PRP) & $\begin{array}{c}\text { Inhibition of platelet } \\
\text { aggregation, antithrombotic } \\
\text { activity (prolongation of } \\
\text { APTT, inhibition of factor } \\
\text { VIII activities) }\end{array}$ & & [27] \\
\hline $\begin{array}{l}\text { (6) Timosaponin A-III (50, } 60 \text { and } \\
100 \mu \mathrm{g} / \mathrm{mL} \text { ) }\end{array}$ & $\begin{array}{l}\text { Male Wistar rats; male } \\
\text { Balb/c mice (PRP and } \\
\text { washed blood platelets) }\end{array}$ & $\begin{array}{l}\text { Inhibitory effects on } \\
\text { ADP-induced platelet } \\
\text { aggregation; delayed } \\
\text { thromboplastin time; } \\
\text { antithrombotic activities }\end{array}$ & & {$[20,21,24]$} \\
\hline
\end{tabular}


Table 1. Cont.

\begin{tabular}{|c|c|c|c|}
\hline $\begin{array}{l}\text { No and Compound Name, } \\
\text { Concentration Used }\end{array}$ & Model & Chemical Structure & Reference \\
\hline $\begin{array}{l}\text { (7) Timosaponin B-II (50 and } \\
100 \mu \mathrm{g} / \mathrm{mL} \text { ) }\end{array}$ & $\begin{array}{c}\text { Male Wistar rats; New } \\
\text { Zealand white rabbits (PRP) }\end{array}$ & $\begin{array}{l}\text { Inhibitory effects on } \\
\text { ADP-induced platelet } \\
\text { aggregation; delayed } \\
\text { thromboplastin time; } \\
\text { antithrombotic activities }\end{array}$ & {$[20,24,28]$} \\
\hline & \multicolumn{3}{|c|}{ Triterpenoid saponins } \\
\hline $\begin{array}{c}\mathbf{( 8 )} \\
2 \alpha, 3 \alpha, 19 \alpha, 23 \text {-tetrahydroxyurs } \\
-12,20(30) \text {-dien-28-oic acid } \\
(1-50 \mu \mathrm{M})\end{array}$ & Rats (PRP) & $\begin{array}{c}\text { Inhibitory effects on } \\
\text { ADP-induced platelet } \\
\text { aggregation }\end{array}$ & [29] \\
\hline
\end{tabular}


Table 1. Cont.

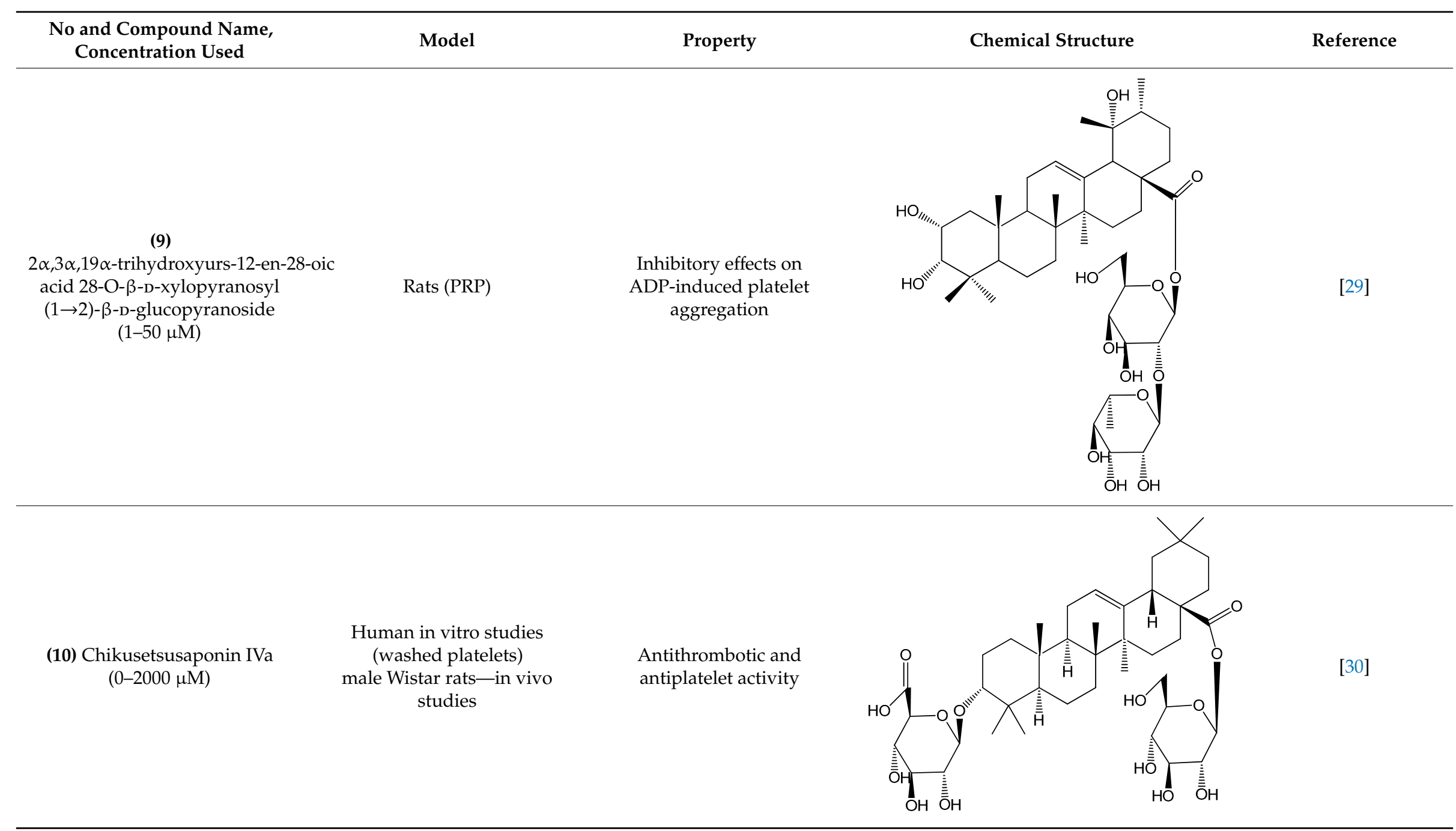


Table 1. Cont

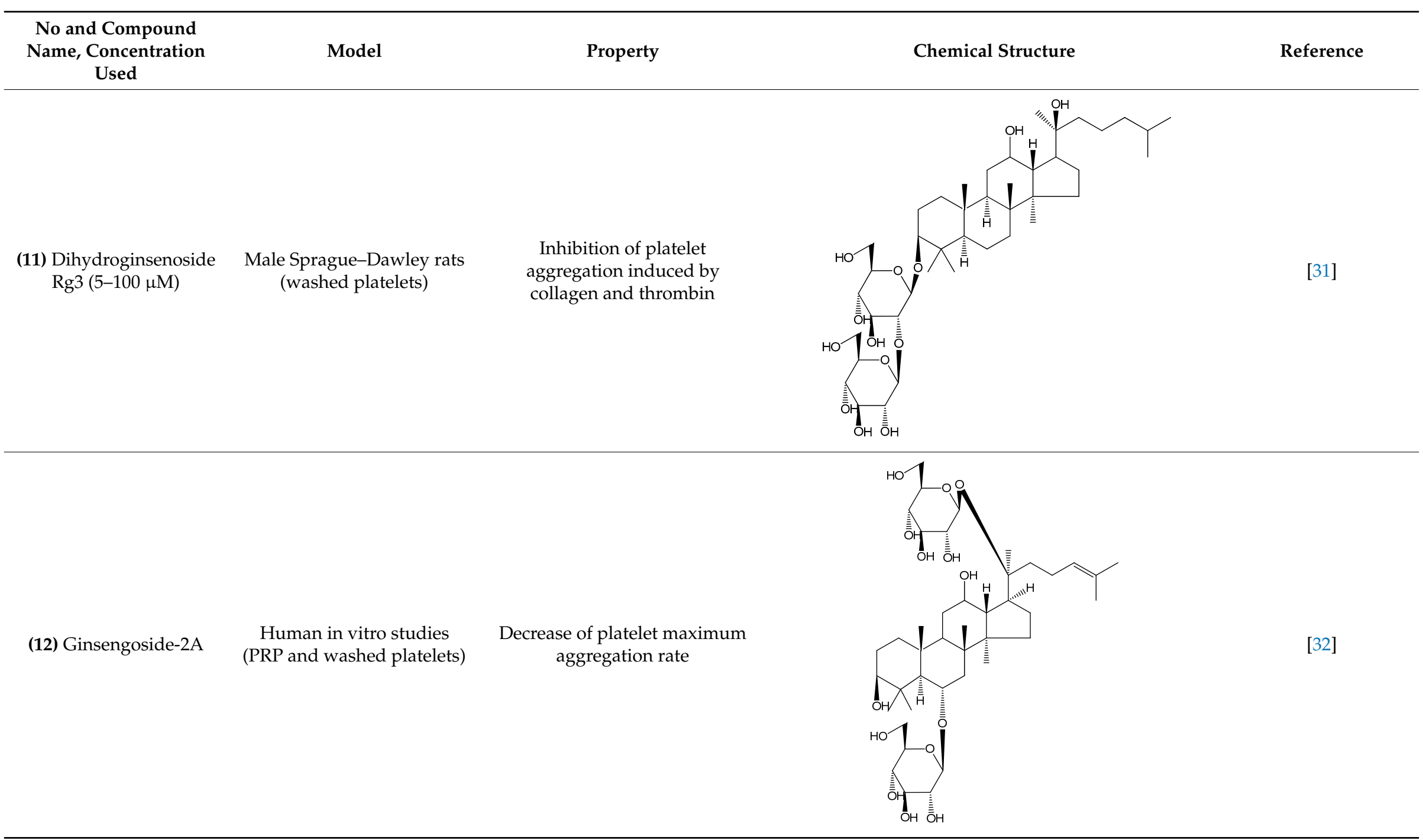


Table 1. Cont.

\begin{tabular}{|c|c|c|c|c|}
\hline $\begin{array}{l}\text { No and Compound Name, } \\
\text { Concentration Used }\end{array}$ & Model & Property & Chemical Structure & Reference \\
\hline $\begin{array}{l}\text { (13) Ginsenoside 20(R)-Rg3 } \\
(2.5-10 \mu \mathrm{M})\end{array}$ & Male ICR mice (PRP) & $\begin{array}{c}\text { Inhibition of platelet } \\
\text { aggregation induced by } \\
\text { ADP, collagen, arachidonic } \\
\text { acid and U46619 (mimic } \\
\left.\text { agent of } \mathrm{TXA}_{2}\right)\end{array}$ & & [33] \\
\hline $\begin{array}{l}\text { (14) Ginsenoside 20(S)-Rg3 } \\
(2.5-10 \mu \mathrm{M})\end{array}$ & Male ICR mice (PRP) & $\begin{array}{l}\text { Inhibition of platelet } \\
\text { aggregation induced by } \\
\text { ADP, collagen, arachidonic } \\
\text { acid and U46619 (mimic } \\
\left.\text { agent of } \mathrm{TXA}_{2}\right)\end{array}$ & & [33] \\
\hline
\end{tabular}


Table 1. Cont.

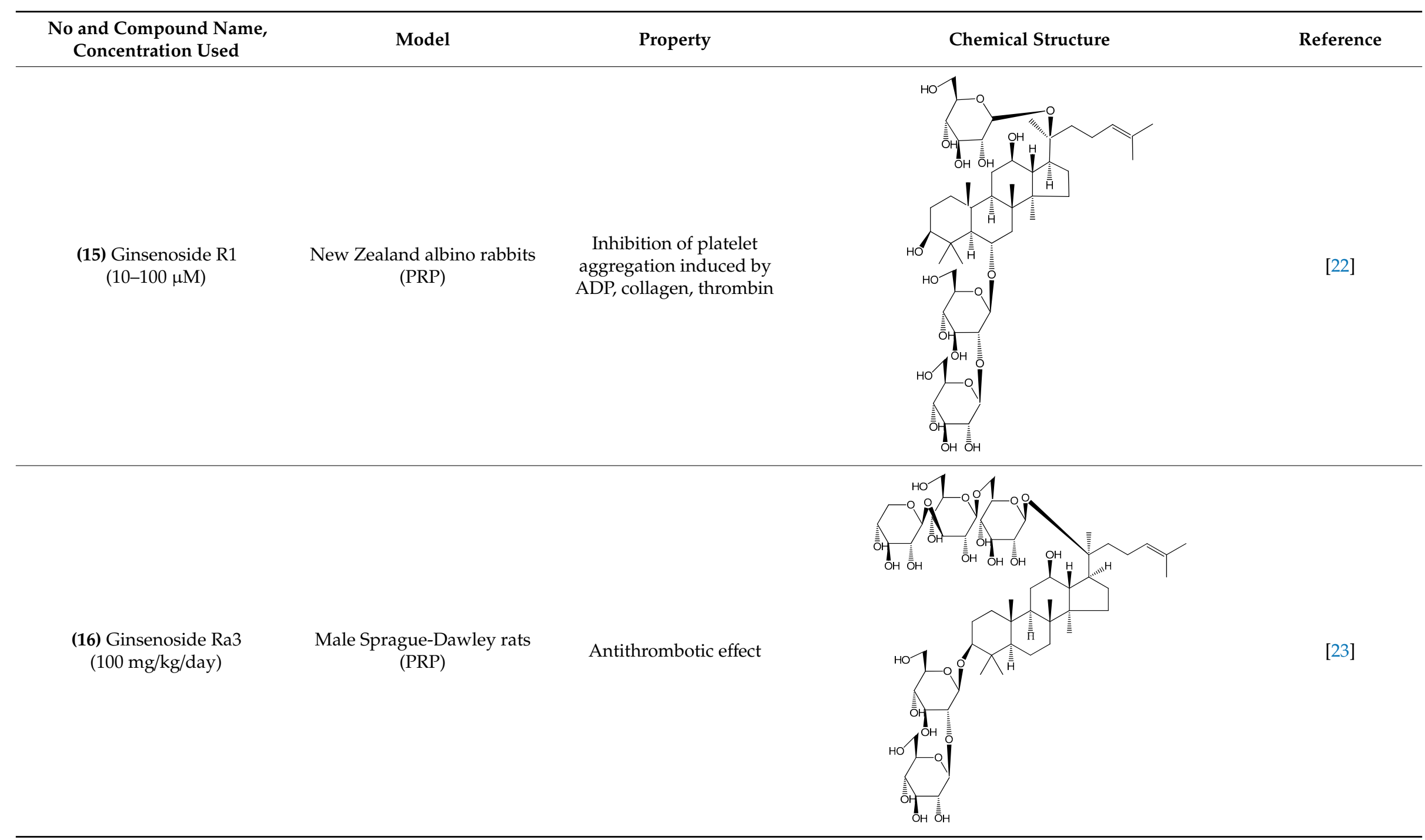


Table 1. Cont

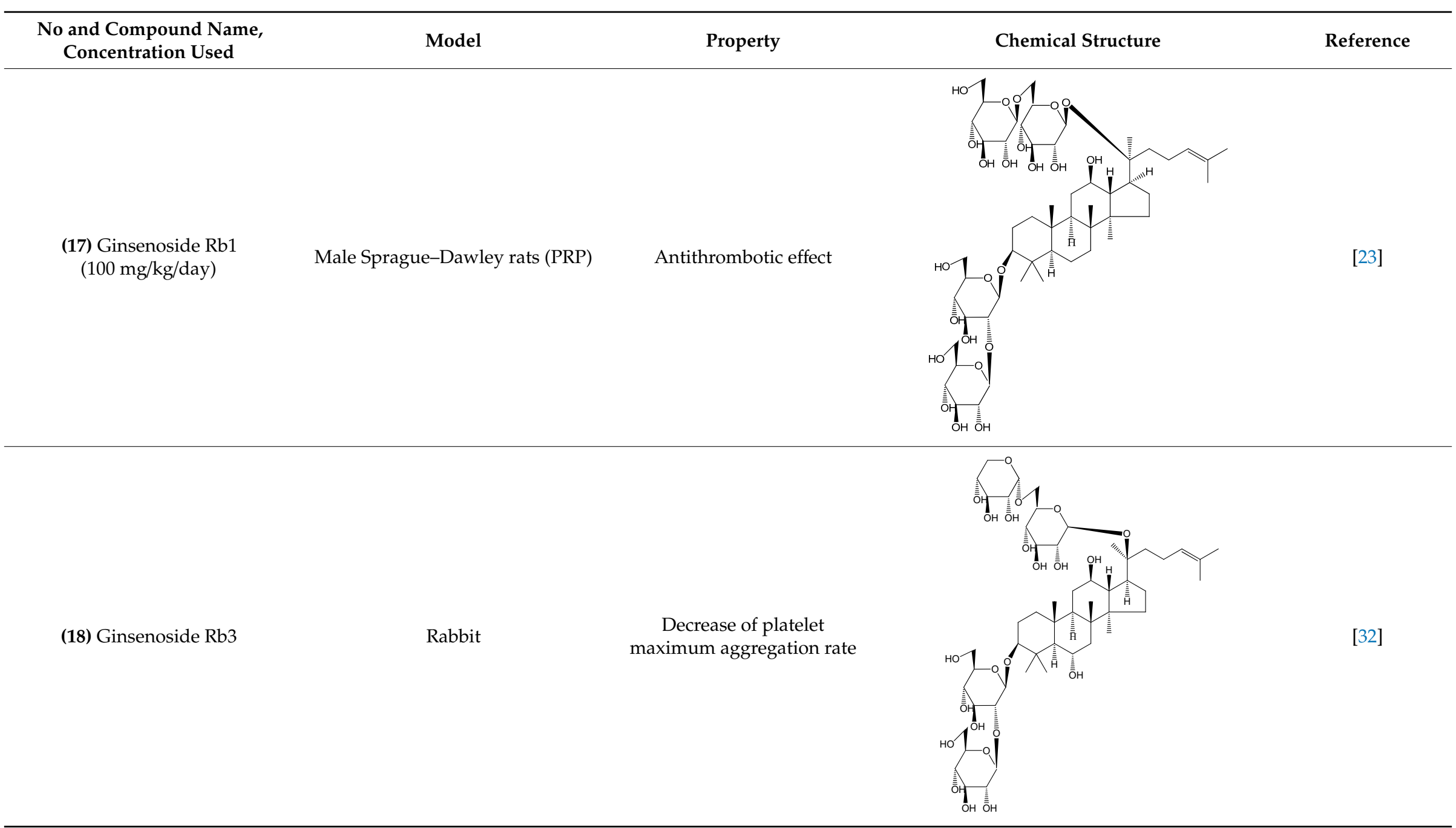


Table 1. Cont.

\begin{tabular}{|c|c|c|c|c|}
\hline $\begin{array}{l}\text { No and Compound Name, } \\
\text { Concentration Used }\end{array}$ & Model & Property & Chemical Structure & Reference \\
\hline $\begin{array}{l}\text { (19) Ginsenoside Rd (100 } \\
\mathrm{mg} / \mathrm{kg} / \text { day })\end{array}$ & Male Sprague-Dawley rats (PRP) & Antithrombotic effect & & [23] \\
\hline $\begin{array}{l}\text { (20) Ginsenoside Rg1 } \\
(10-100 \mu \mathrm{M})\end{array}$ & $\begin{array}{l}\text { New Zealand albino rabbits (PRP) } \\
\text { Human in vitro plasma coagulation } \\
\text { assays (PRP) }\end{array}$ & $\begin{array}{l}\text { Inhibition of platelet } \\
\text { aggregation induced by } \\
\text { ADP, collagen, thrombin } \\
\text { Anticoagulation activity }\end{array}$ & & $\begin{array}{l}{[22]} \\
{[34]}\end{array}$ \\
\hline
\end{tabular}


Table 1. Cont

\begin{tabular}{|c|c|c|c|c|}
\hline $\begin{array}{l}\text { No and Compound Name, } \\
\text { Concentration Used }\end{array}$ & Model & Property & Chemical Structure & Reference \\
\hline $\begin{array}{l}\text { (21) Ginsenoside Rg2 } \\
(0.05 \mathrm{mg} / \mathrm{mL})\end{array}$ & $\begin{array}{c}\text { Human in vitro plasma coagulation } \\
\text { assays (PRP) }\end{array}$ & Anticoagulation activity & & {$[34]$} \\
\hline $\begin{array}{l}\text { (22) Ginsenoside Rg5 } \\
(2.5-10 \mu \mathrm{M})\end{array}$ & Male ICR mice (PRP) & $\begin{array}{l}\text { Inhibition of platelet } \\
\text { aggregation induced by } \\
\text { ADP, collagen, arachidonic } \\
\text { acid and } U 46619(\text { mimic } \\
\text { agent of TXA } 2)\end{array}$ & & [33] \\
\hline
\end{tabular}


Table 1. Cont.

\begin{tabular}{|c|c|c|c|c|}
\hline $\begin{array}{l}\text { No and Compound Name, } \\
\text { Concentration Used }\end{array}$ & Model & Property & Chemical Structure & Reference \\
\hline $\begin{array}{l}\text { (23) Ginsenoside Re } \\
(10-100 \mu \mathrm{M})\end{array}$ & $\begin{array}{l}\text { New Zealand albino rabbits (PRP) } \\
\text { Male Sprague-Dawley rats (PRP) }\end{array}$ & $\begin{array}{l}\text { Inhibition of platelet } \\
\text { aggregation induced by } \\
\text { ADP, collagen, thrombin } \\
\text { Antithrombotic effect }\end{array}$ & & $\begin{array}{l}{[22]} \\
{[23]}\end{array}$ \\
\hline $\begin{array}{l}\text { (24) Ginsenosides Rk1 } \\
(2.5-10 \mu \mathrm{M})\end{array}$ & Male Sprague-Dawley rats (PRP) & $\begin{array}{l}\text { Inhibition of platelet } \\
\text { aggregation induced by } \\
\text { ADP, collagen, arachidonic } \\
\text { acid and U46619 (mimic } \\
\left.\text { agent of } \mathrm{TXA}_{2}\right)\end{array}$ & & {$[3,33]$} \\
\hline
\end{tabular}


Table 1. Cont

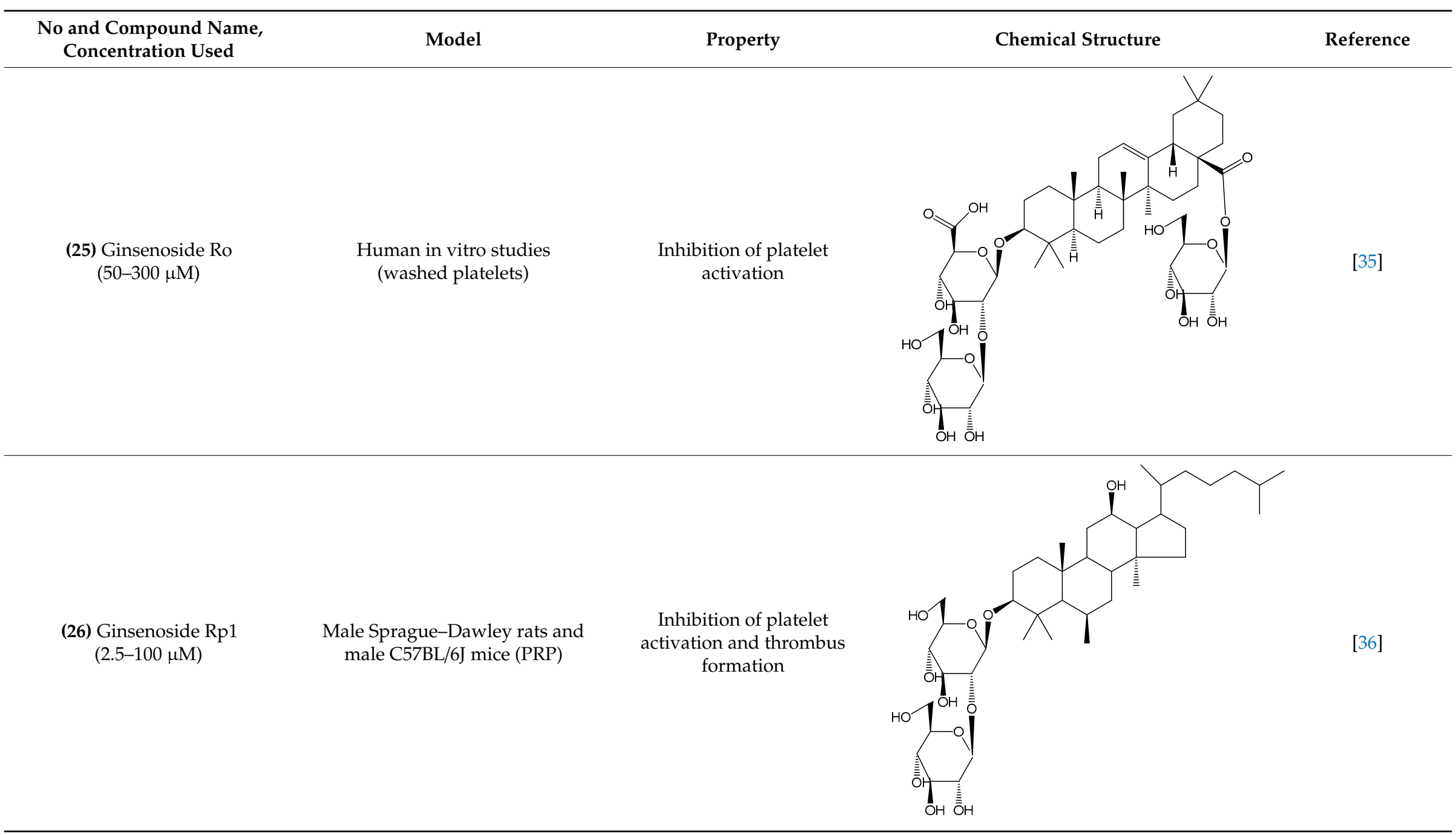


Table 1. Cont.

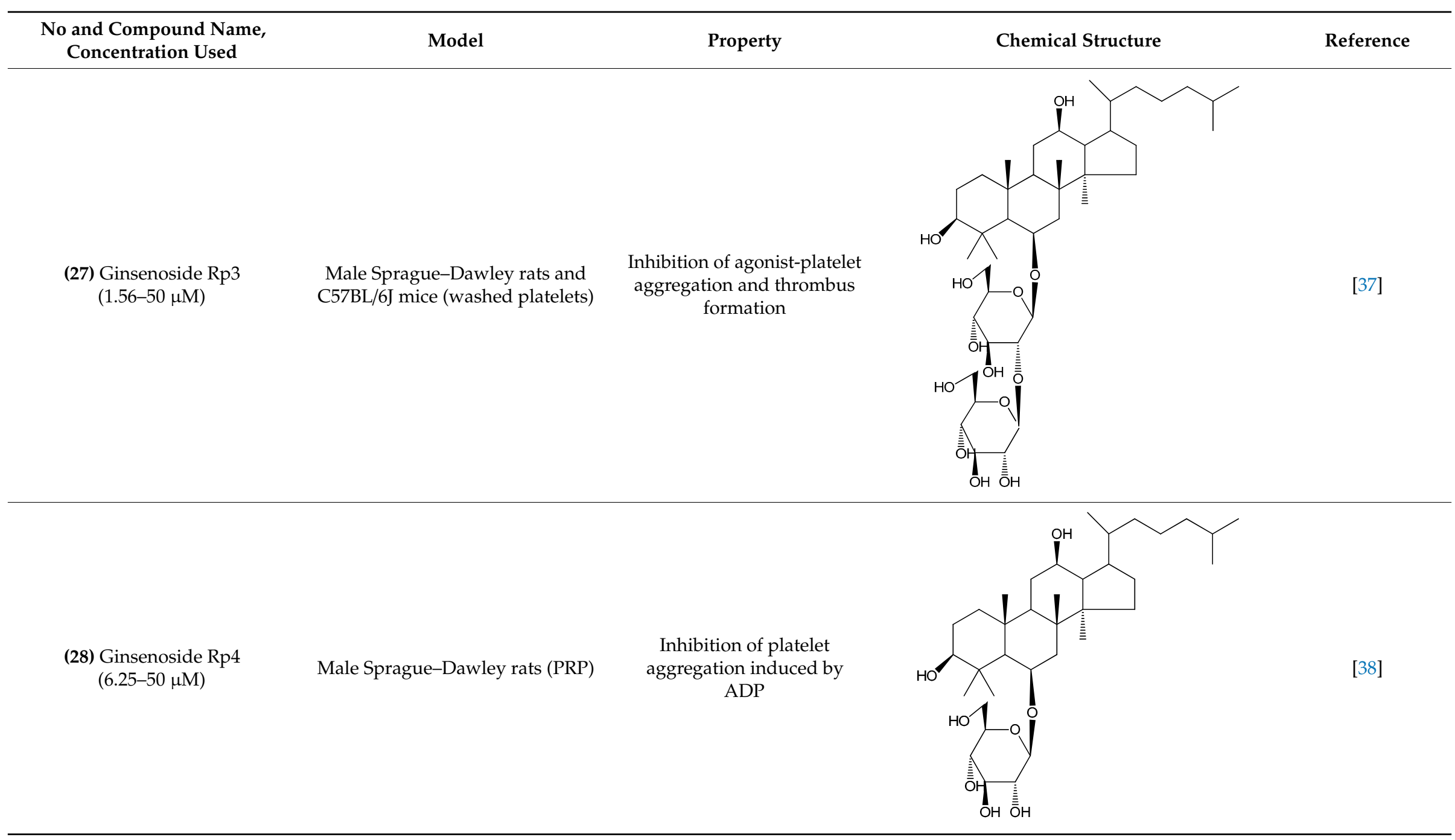


Table 1. Cont.

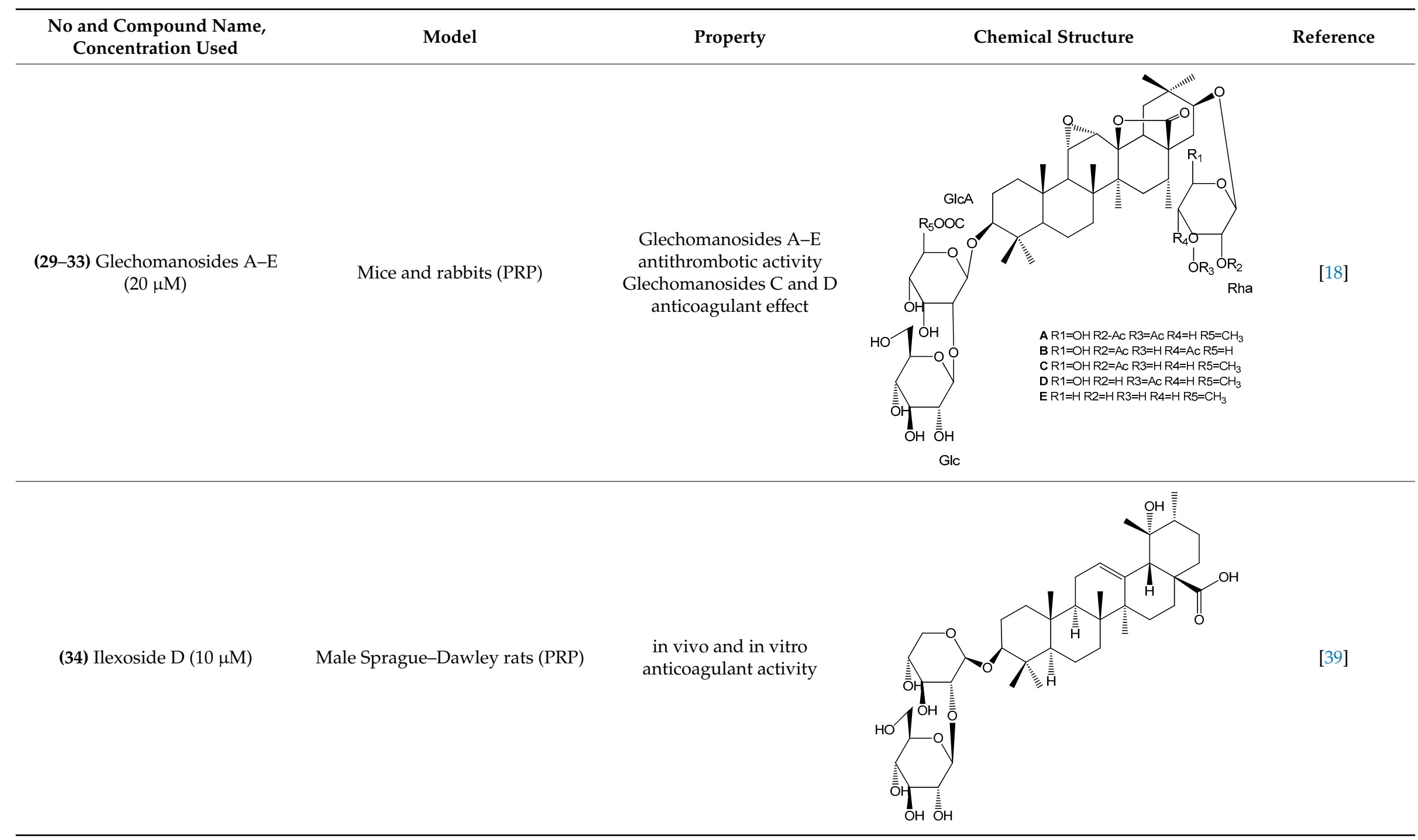


Table 1. Cont.

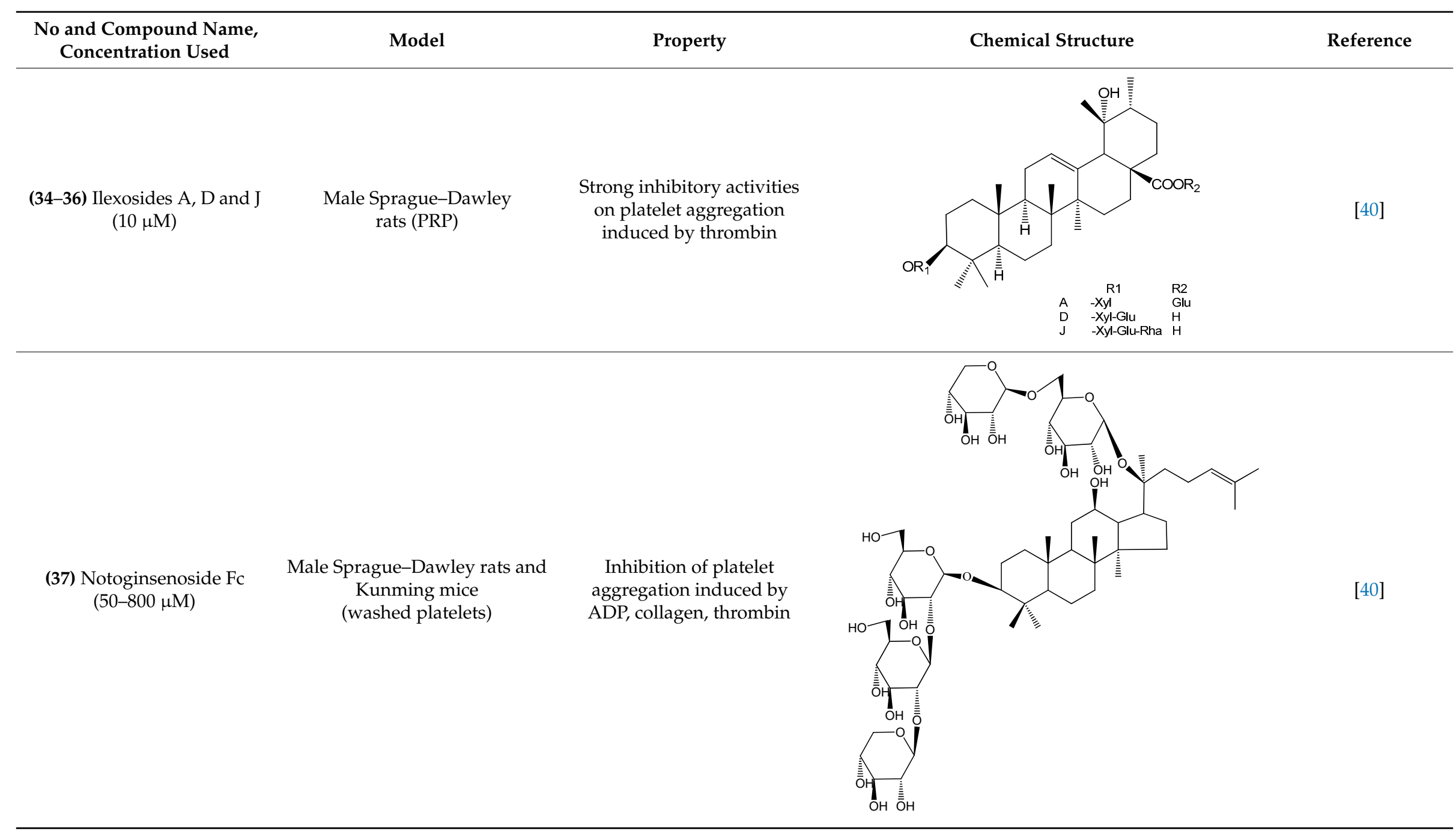


Table 1. Cont.

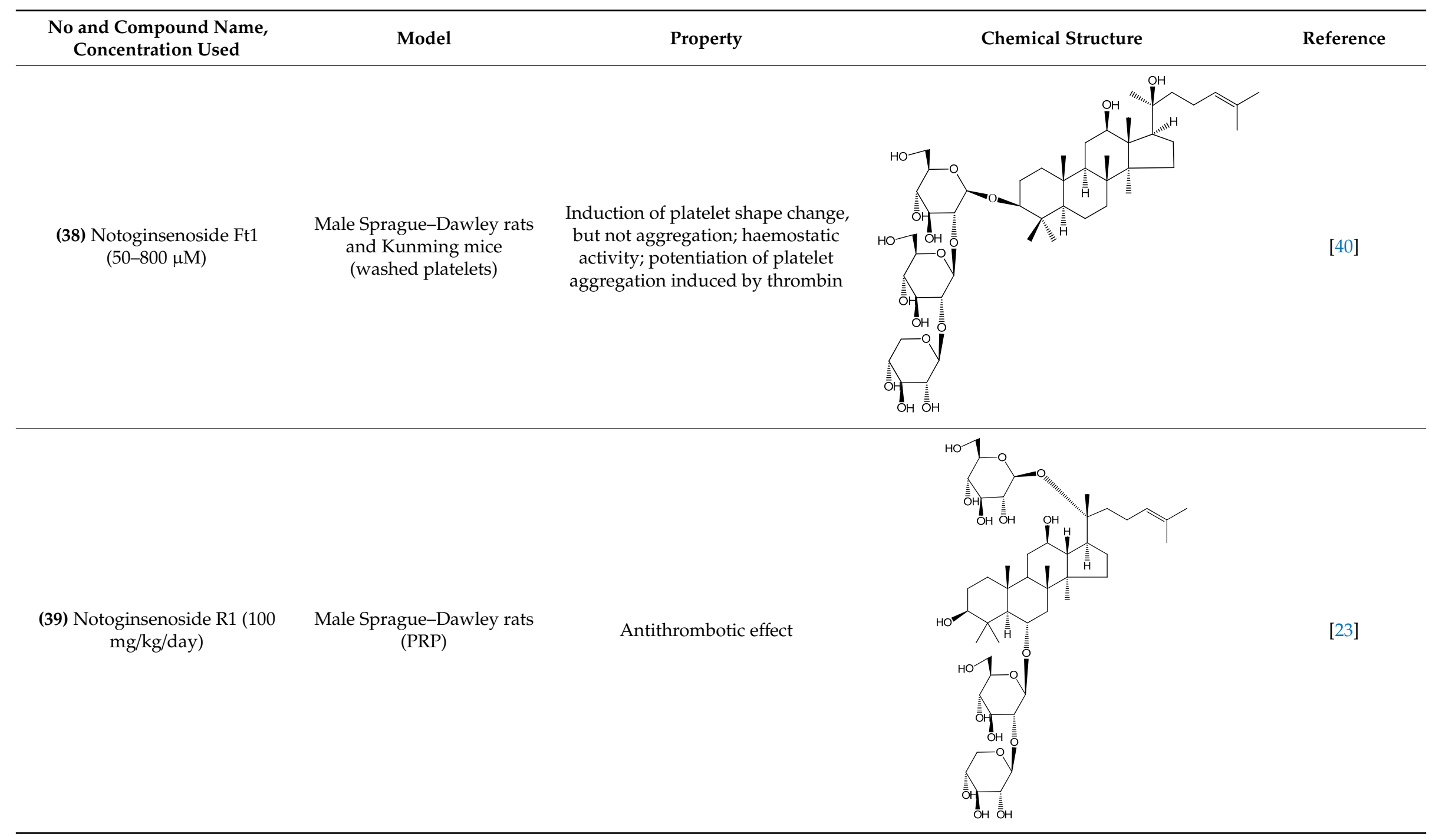


Table 1. Cont.

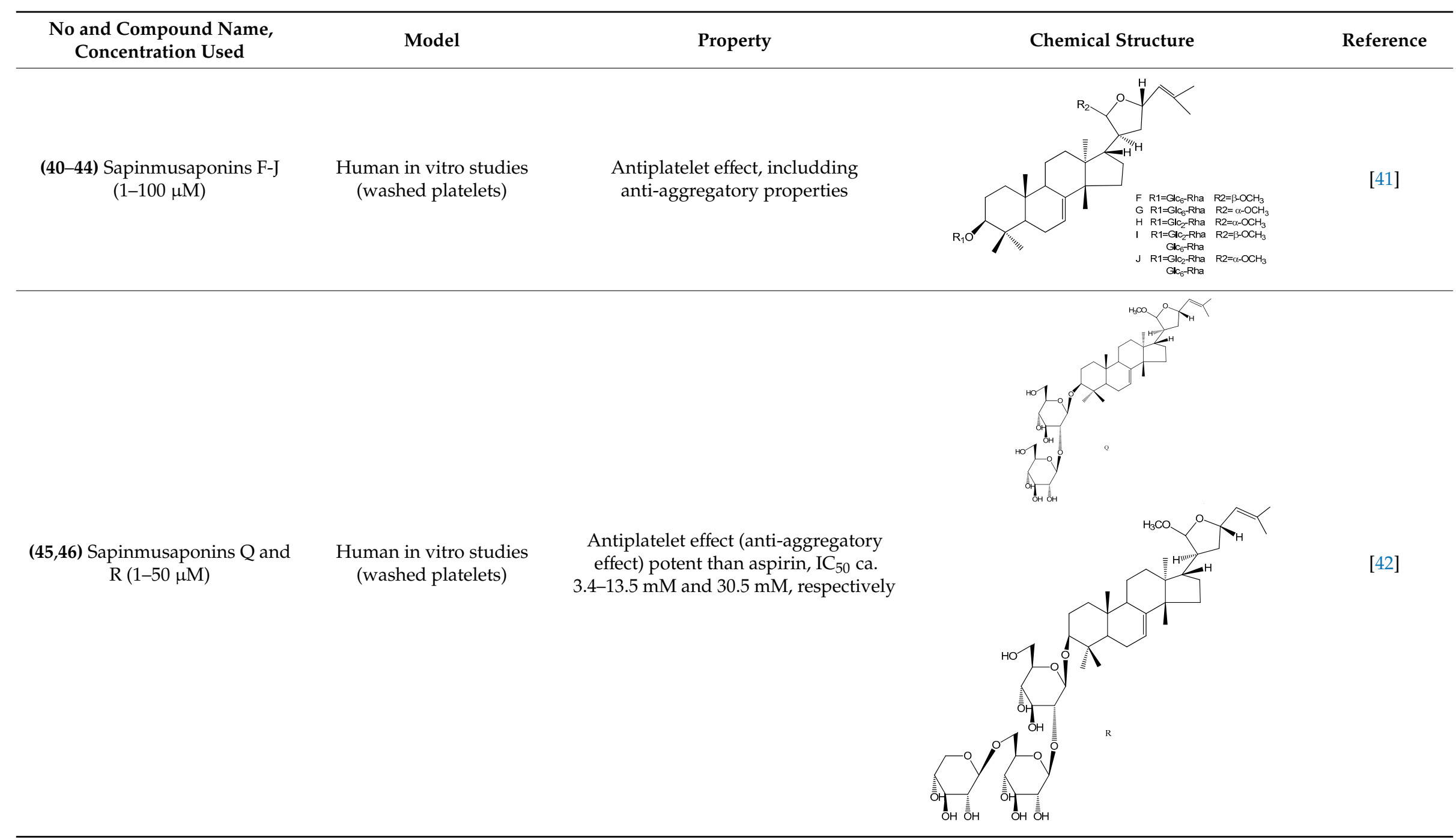




\section{The Molecular Mechanism of Saponin Action as Modulators of the Coagulation System}

\subsection{Arachidonic Acid Pathway}

Arachidonic acid (AA) is released from the phospholipid molecules of the cell membranes by the action of phospholipase $\mathrm{A}_{2}\left(\mathrm{PLA}_{2}\right)$; this is important for the formation of prostanoids, which play a role in platelet activation and inactivation mechanisms [43]. Arachidonic acid (AA) is the preferred substrate for the constitutive cyclooxygenase enzyme (COX-1) that enables the production of prostaglandin endoperoxides (PG). COX-1 converts AA into two transient endoperoxides, prostaglandin $\mathrm{G}_{2}\left(\mathrm{PGG}_{2}\right)$ and prostaglandin $\mathrm{H}_{2}\left(\mathrm{PGH}_{2}\right)$. These compounds are then converted by thromboxane synthetase to thromboxane $\mathrm{A}_{2}\left(\mathrm{TXA}_{2}\right)$, which is the major metabolite in platelets [44]. TXA 2 is rapidly and nonenzymatically converted to inactive and stable thromboxane $\mathrm{B}_{2}\left(\mathrm{TXB}_{2}\right)$. Thromboxane $\mathrm{A}$ induces shape changes and aggregation among platelets, as well as their degranulation [45].

$\mathrm{TXA}_{2}$ affects cellular signal transmission by interacting with a specific protein receptor located on the cell surface. This thromboxane receptor (TP) is encoded by the TBXA2R gene and belongs to the $G$ protein-coupled superfamily of seven-transmembrane receptors [46]. As TXA 2 is known to participate in the pathogenesis of arterial thrombosis, a number of anti-TXA $\mathrm{A}_{2}$ agents have been developed to inhibit its biosynthesis or act as TP antagonists. The process of platelet activation is regulated by various factors, one of which is the level of the secondary messenger's adenosine 3', 5'-cyclic monophosphate (cAMP) and guanosine 3',5'-cyclic monophosphate (cGMP): Increases in the intracellular levels of cAMP and cGMP result in inhibition of agonist-induced platelet activation, aggregation and adhesion. At the same time, arachidonate 12-lipoxygenase (12-LOX) converts AA into 12-hydroxy-5,8,10,14-eicosatetraenoic acid (12-HETE) [43,44,47].

The ginsenoside Rk1 (24) isolated from Panax ginseng C.A.Mey. has been found to demonstrate a stronger response to AA-induced platelet aggregation than acetylsalicylic acid. Rk1 is known to reduce the levels of $\mathrm{TXB}_{2}$ and 12-HETE. It is believed that Rk1 modulates intracellular calcium level, known to induce platelet activation, by increasing 12-LOX translocation from the cytosol to the membrane; this movement reduces the level of $\mathrm{Ca}^{2+}$, thus decreasing that of 12-HETE [48].

The steroidal saponin timosaponin AIII (TAIII) [3-O- $\beta$-D-glucopyranosyl-( $1 \rightarrow 2)$ - $\beta$-D-galactopyranoside sarsasapogenin] (6) has also been found to inhibit the $\mathrm{TXA}_{2}$ receptor. TAIII, first isolated from Anemarrhena asphodeloides Bunge, has been found to inhibit platelet aggregation by suppressing ADP secretion, regardless of the increase in CAMP and CGMP; it has also been found to inhibit the production of TXA 2 in platelets. TAIII has also been shown to inhibit $\mathrm{Gq}$ rather than $\mathrm{G}_{12 / 13}$ activation through the thromboxane receptor [21].

\subsection{GPVI Signaling Pathway and Enzymatic Cascades}

The binding of collagen to the glycoprotein VI (GPVI) receptor causes the phosphorylation of the $\gamma$-chain tyrosine of the Src family kinase-mediated Fc receptor, followed by the tyrosine of spleen tyrosine kinase (Syk) and that of linker for activation of T cells (LAT). On the cell surface, GPVI may be expressed as monomeric and dimeric forms, with a single GPVI molecule associating with a single Fc receptor $\gamma$-chain dimer [49]. Subsequent activation of LAT and PI3K mediates the recruitment and tyrosine phosphorylation of phospholipase C $\gamma 2$ (PLC $\gamma 2$ ); this results in 1,2-diacylglycerol (DAG) and inositol-1,4,5-trisphosphate (IP3) release, protein kinase C (PKC) activation, and $\mathrm{Ca}^{2+}$ mobilization.

Such platelet activation affects the release of fibrinogen and P-selectin, together with various prothrombotic factors, such as thrombin, adenosine diphosphate (ADP) and TXA 2 . Mitogen-activated protein kinases (MAPKs), such as ERK-2, p38-MAPK and JNK-1, are also activated by agonist-stimulated platelets. It is suggested that collagen-induced activation of PI3K and PLC may be upstream events mediating ERK-2 and p38-MAPK phosphorylation [36,49-51].

It was found that dihydroginsenoside Rg3 (11) from Panax ginseng may suppress the phosphorylation of ERK-2, but not that of p38-MAPK during collagen-stimulated aggregation. As the intracellular concentration of $\mathrm{Ca}^{2+}$ is often found to increase as a result of such stimulation, it is possible 
that its level may play a role in collagen stimulation [31]. Panaxatriol saponins (PTS), isolated from an extract of Panax notoginseng known to demonstrate antiplatelet activity, have also been found to suppress cellular signaling by reducing ERK-2 and p38 phosphorylation [22].

Ginsenoside-Rp1 (3-O- $\beta$-D-glucopyranosyl-( $1 \rightarrow 2)-\beta$-D-glucopyranosyl dammarane-3 $\beta, 12 \beta$-diol) (26) inhibits collagen-induced platelet activation and thrombus formation through modulation of early GPVI signaling events; this effect involves the stimulation of vasodilator-stimulated phosphoprotein (VASP), and ERK-2 and p38-MAPK [36]. VASP is a major substrate for cAMP-dependent protein kinase A (PKA) and cGMP-dependent protein kinase G (PKG) and is an actin- and profilin-binding protein expressed in platelets [52].

Another saponin that affects platelet aggregation by exerting an influence on cyclic cAMP and cGMP nucleotides is dihydroginsenoside $\mathrm{Rg} 3$, a relatively stable chemical derivative of the triterpene saponin ginsenoside Rg3 isolated from Panax ginseng. Interestingly, dihydroginsenoside Rg3 has been found to elevate cyclic AMP production in resting platelets, but not cyclic GMP production. It is possible that matrix metalloproteinase and vasodilator-stimulated phosphoprotein play a role in this process [31].

Ginsenoside-Rp1 is known to increase the cAMP level and suppress collagen-induced ATP-release, thromboxane secretion, $\mathrm{p}$-selectin expression, $\mathrm{Ca}^{2+}$ mobilization and integrin $\alpha_{\mathrm{IIb}} \beta_{3}$ activation; it has also been found to reduce p38-MAPK and ERK-2 activation and inhibit tyrosine phosphorylation of many kinases (Fyn, Lyn, Syk, LAT, PI3K and PLC $\gamma 2$ ) of the GPVI signaling pathway. Ginsenoside-Rp1 was also observed to inhibit in vivo thrombus formation and ex vivo platelet aggregation and ATP secretion without interfering with coagulation time [36]. In turn, ginsenoside Rp3 (27) modulates agonist-induced platelet activation and thrombus formation by integrin $\alpha_{\mathrm{IIb}} \beta_{3}$ activation, MAPK signaling, Src, PLC $\gamma 2$ and PI3K/Akt activation, and VASP stimulation [37]. Additionally, ginsenoside Ro (25), an oleanane-type saponin, inhibited thrombin-induced platelet aggregation and reduced the binding of fibrinogen to $\alpha \mathrm{IIb} / \beta 3$ via cAMP-dependent vasodilator-stimulated phosphoprotein phosphorylation. In addition, ginsenoside-Ro abrogated clot retraction reflecting the intensification of thrombus [53].

Notoginsenoside Fc (37) is a novel saponin isolated from Panax notoginseng. The phospholipase C- $\gamma 2$ has been proposed as the focal point of notoginsenoside Fc antiplatelet activity, which is believed to act through the downregulation of DAG, protein kinase C, TXA2 and IP3. In contrast, the notoginsenoside $\mathrm{Ft} 1$ is believed to promote platelet aggregation by potentiating signaling by the PLC $\gamma 2-I P 3 / D A G-\left(\mathrm{Ca}^{2+}\right) / \mathrm{PKC}-\mathrm{TXA} 2$ pathway (38). Ft1 is isolated from Panax notoginseng in the same way as notoginsenoside $\mathrm{FC}_{\mathrm{C}}[40]$.

The main components of the arachidonic acid and GPVI signaling pathways, discussed above, are shown in Figure 2. Several of the saponins listed in Table 1 have the ability to inhibit ADP-induced platelet aggregation. These compounds are therefore antagonists of ADP-activated transmembrane receptors such as $\mathrm{P}_{2} \mathrm{Y}_{1}$ and $\mathrm{P}_{2} \mathrm{Y}_{12}$. Both of these receptors interact with $\mathrm{G}$ proteins, but their downstream effectors are in different signaling pathways. The activation of a $\mathrm{P}_{2} \mathrm{Y}_{1} \mathrm{ADP}$ receptor, which belongs to the Gq protein-coupled receptors, leads to the activation of phospholipase C (PLC), whereas activation of the $\mathrm{P}_{2} \mathrm{Y}_{12}$ receptor coupled to the Gi protein triggers adenylate cyclase activity. It has been suggested that activation of both receptors is required for a complete platelet response to ADP [54,55]. Figure 2 shows the potential effectors inhibited by ADP receptor inhibitors. 


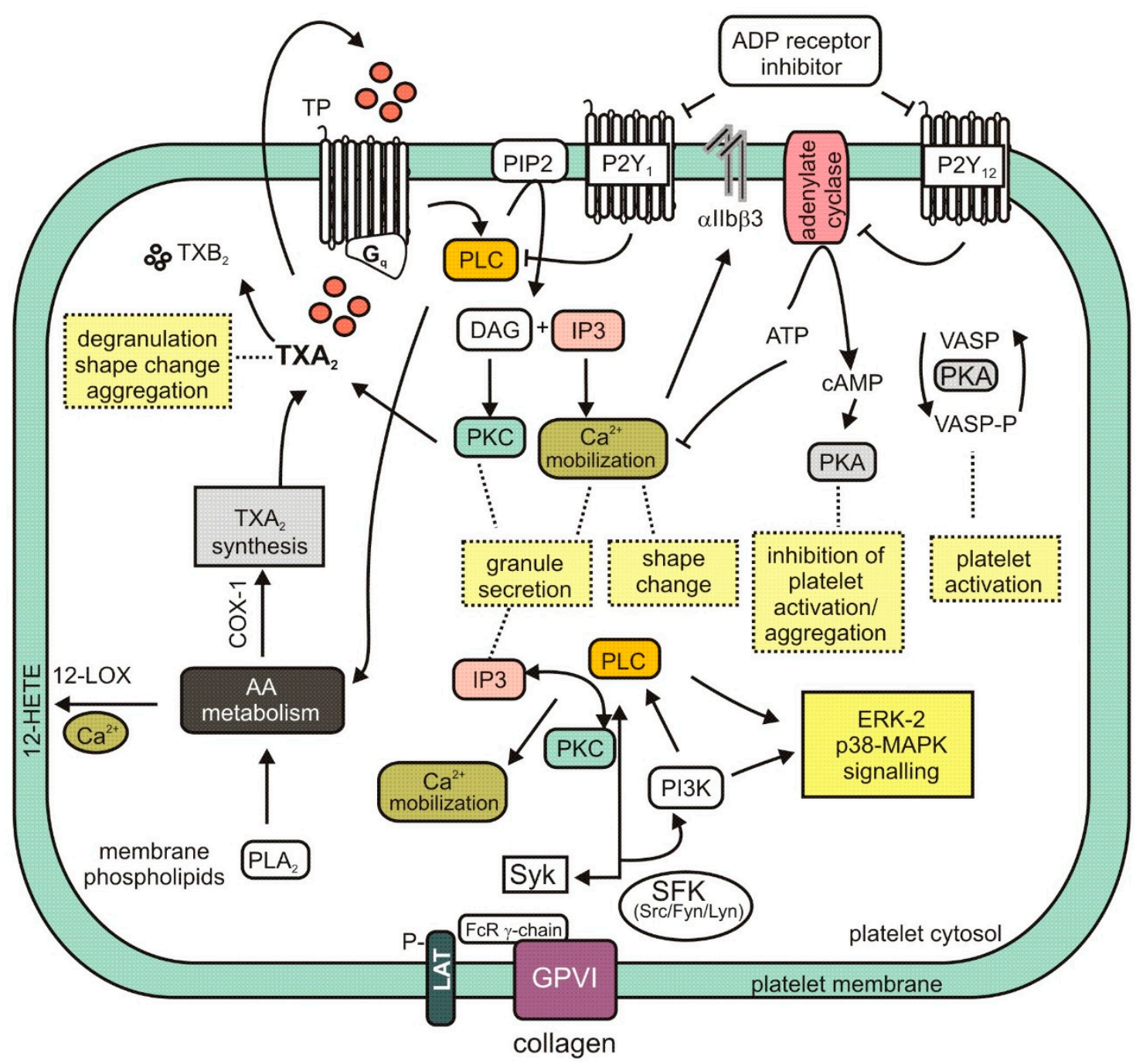

Figure 2. Mechanism of platelet activity modulation showing selected intracellular signaling pathways. 12-HETE, 12-hydroxy-5,8,10,14-eicosatetraenoic acid; 12-LOX, arachidonate 12-lipoxygenase; AA, arachidonic acid; ADP, adenosine 5' -diphosphate; cAMP, adenosine $3^{\prime}$ ', 5' -cyclic monophosphate; COX-1, cyclooxygenase-1; DAG, 1,2-diacylglycerol; GPVI, glycoprotein VI; IP3, inositol-1,4,5-trisphosphate; LAT, linker for activation of T cells; MAPK, mitogen-activated protein kinase; $\mathrm{P}_{2} \mathrm{Y}_{1}$, ADP receptor; $\mathrm{P}_{2} \mathrm{Y}_{12}$, ADP receptor; PI3K, phosphoinositide 3-kinase; PIP2, phosphatidylinositol biphosphate; PKA, protein kinase A; PKC, protein kinase C; PLA2, phospholipase A2; PLC, phospholipase C; SFK, Src-family kinase; Syk, spleen tyrosine kinase; TP, thromboxane receptor; $\mathrm{TXA}_{2}$, thromboxane $\mathrm{A}_{2} ; \mathrm{TXB}_{2}$, tromboxane $\mathrm{B}_{2}$; VASP, vasodilator-stimulated phosphoprotein.

\subsection{Inhibition of Tissue Factor Expression}

Tissue factor (TF) is the key element in triggering the primary procoagulant pathway of coagulation and is an important factor associated with the state of hypercoagulability in venous thrombosis. TF dysfunction may result in the occurrence of pulmonary embolism, chronic venous insufficiency or post-thrombotic syndrome, among others [56]. TF is a transmembrane protein acting as a high-affinity nonenzymatic cofactor for factor (F)VIIa in the extrinsic tenase (TF-FVIIa) complex, acting in turn as an activator of the coagulation protease cascade. TF stabilizes the FVIIa catalytic site on the plasma membrane, allowing optimal interaction with substrates FIX and FX [57-59].

TF is produced by macrophages and microvesicles in atherosclerotic plaques and activated cells within the vasculature, as well as perivascular cells, all of which are known to activate coagulation. It is expressed in an organ-specific manner, being observed at high concentrations in the brain, lung, 
heart, uterus and placenta, and low concentrations in skeletal muscles and joints. This phenomenon suggests that TF provides additional hemostatic protection to a selected group of important organs. However, TF-dependent activation of blood coagulation needs to be tightly regulated to maintain hemostasis and prevent thrombosis; the first level of this regulation is believed to be based on the management of TF gene/protein expression [56].

It has been shown that the natural D39 (3) steroidal saponin isolated from Liriope muscari (Decne.) L.H. Bailey downregulates endothelial TF expression and venous thrombus formation by modulating the PI3K/Akt/GSK3 $\beta$ and NF-KB signaling pathways. It has been proposed that D39 exerts this activity by binding to, and thus deactivating, NMMHC IIA (non-muscular myosin heavy chain IIA), and inhibiting the dissociation of NMMHC II2 from tumor necrosis factor receptor 2 (TNFR2) [60,61].

\section{Toxicology and Safety of Saponins}

The rate of absorption of saponins in the human digestive tract is very low, except for those whose glycosyl groups are hydrolyzed. This process can occur under natural conditions through heating (physically), acidolysis (chemically) and through microbiological transformation. The intestinal flora exerts a strong metabolic effect on saponins, mainly through the hydrolysis of sugar [7]. For example, the oral bioavailability of ginsenosides $\mathrm{Ra} 3(\mathbf{1 6}), \mathrm{Rb} 1 \mathrm{(17)}$ and $\mathrm{Rd}(19)$ was found to be $0.1-0.2 \%$, and $0.2-0.6 \%$ for the ginsenosides Re (23), Rg1 (20), and notoginsenoside R1 (39) [62].

Only six saponin drugs have been registered to the DrugBank database [63] (version 5.1.4, accessed in January 2020). The first is aglycone Smilagenin [(25R)-5 $\beta$-spirostan-3 $\beta$-ol)], and the next five are various other ginsenosides. In the case of ginsenoside $C$, it has been noted that the risk of thrombosis may be associated when administered in combination with other drugs.

A pharmacological interaction has also been demonstrated between saponins from Panax notoginseng and aspirin regarding the absorption process; however, the research was conducted on an animal model. A showed a marked increase in the absorption of notoginsenoside $\mathrm{R}_{1}$, ginsenosides $\mathrm{Rg} 1, \mathrm{Rb} 1, \mathrm{Re}$ and $\mathrm{Rd}$ was observed when aspirin was present $[64,65]$.

Few studies have examined the toxic doses associated with saponin use. Nevertheless, these compounds have been found to be are highly toxic when administered intravenously in higher animals; however, this toxicity falls to low levels when administered orally. Some saponins present in food do not possess significant oral toxicity [66]. A study of the sub-acute and chronic toxic effects of total steroidal extracts from Dioscorea zingiberensis C.H. Wright on internal organs and biochemical indicators found that dogs could tolerate the extracts at doses up to $500 \mathrm{mg} / \mathrm{kg}$ with $\mathrm{LD}_{50}$ greater than $3000 \mathrm{mg} / \mathrm{kg}$ body weight [67]. Due to their toxic effects on some mammals, saponins are proposed as rodenticides $[68,69]$. The oral $\mathrm{LD}_{50}$ of total saponins and tannins from Dialium guineense Willd. stem bark has been found to be greater than $5000 \mathrm{mg} / \mathrm{kg}$ body weight for male Sprague-Dawley rats [70], while that observed for saponins extracted from the rind of Citrullus colocynthis (L.) Schrad. was found to be $79.43 \mathrm{mg} / \mathrm{rat}$ for Narway rats [71]. Saponins isolated from Albizia julibrissin Durazz have also demonstrated reproductive toxicity for female mice, most likely caused by damage to the ovary and uterus [72].

Some triterpene and steroid saponins are unsuitable for medical applications due to their harmful levels of hemolytic toxicity. Such activity is known to depend on both the type of aglycone group and the number and sequence of sugar side chains. Presumably, saponins interact with the cholesterol in the erythrocyte membrane, which results in pore formation, the disruption of the ionic balance and membrane permeabilization [73,74]. de Groot et al. report that $\alpha$-tomatine is a promising saponin in that it demonstrates quite low hemolytic activity; however, it has a high affinity for cholesterol [75]. Sarykayha et al. report that saponins with oleanolic acid in the aglycone group cause significant hemolysis compared to those with a hederagenin aglycone: Aristatoside $\mathrm{C}$, cephoside $\mathrm{A}$ and davisianoside B exhibited significant hemolytic activity on human blood cells when administered at $500 \mu \mathrm{g} / \mathrm{mL}$, the respective values being $89.80 \%, 67.70 \%$ and $66.17 \%$ [76]. 
A study of 41 triterpenoid saponins and sapogenins found that many structure-dependent factors modulate the hemolytic activity, such as skeleton type, location of functional groups and the stereochemical configuration of substituents in aglycone, as well as the complexity of sugar moieties. The presence of polar regions on sapogenins, such as a carboxyl group at position 28 , an $\alpha$-hydroxyl group at position 16 , and/or a $\beta$-hydroxyl group at position 2 , significantly enhanced hemolysis. In contrast, the presence of an $\alpha$-hydroxyl group at position 2 or a hydroxymethyl group at positions 23 or 24 was associated with the decreased hemolytic activity. Additionally, it turned out that the majority of oleanane-type sapogenins showed stronger hemolytic effects than those of the ursane and dammarane types [77].

A modern and safe solution to the problem of saponin toxicity may lie in the organic synthesis of diverse saponins with therapeutic effects accompanied by the systematic study of their biological properties and toxicity $[5,78]$. Even more effective are in silico studies that allow therapeutic saponins to be designed without prior organic synthesis. One such study was performed by Zheng et al. Briefly, two groups of saponins were selected based on literature data, one with hemolytic properties and the other without, and a machine-learning-based hemolytic toxicity classification model was created for them. The study resulted in the design of an innovative program called "e-Hemolytic-Saponin" for the automatic prediction and design of hemolytic/non-hemolytic saponins. The program allowed the analysis of 452 saponins and the creation of a database of hemolytic activity as a guide for the design and synthesis of more non-hemolytic saponins with therapeutic effects [73].

\section{Conclusions}

In recent years, the structure, distribution, and pharmacological importance of saponins have been extensively analyzed, both as a pure compound and as an enriched crude plant extract. Literature data clearly indicate that these compounds have a high anticoagulant/antithrombotic potential that can be used in the prevention and treatment of thromboembolic disease; both in vitro and in vivo models have found steroidal and triterpenoid saponins isolated from various plants to have these properties [18,79-81]. Xiong et al. report that P. notoginseng root and rhizome $(0.5-3.5 \mathrm{mg} / \mathrm{mL})$ demonstrate anticoagulant activity in vitro [11]. Zhang et al. also note that saponins isolated from the roots and rhizomes of $P$. notoginseng may play an important function in treating cardiovascular diseases such as coronary heart diseases, cardiac arrhythmia and angina pectoris [79]. In addition, Dong et al. found $P$. notoginseng saponins to protect human umbilical vein endothelial cells from $\mathrm{H}_{2} \mathrm{O}_{2}$-stimulated oxidative stress [14].

The broad-spectrum anticoagulant/antithrombotic effects of saponins could be derived through several mechanisms of action. For example, the anti-platelet mechanisms of ginsenosides such as Rg3, Rp1, and Rp3 have been associated with elevated cAMP, integrin $\alpha_{I I b} \beta_{3}$ activation, granule secretion, and $\mathrm{Ca}^{2+}$ mobilization; however, other mechanisms may exist for saponins with different structures.

Platelets are activated in many ways, so even with efficient inhibition of platelets by ADP inhibitors such as clopidogrel, prasugrel, or ticagrelor, their activation may occur through other molecular pathways [81]. Whereas, saponins as a group of chemical compounds offer broad anticoagulant activity through various cell signaling pathways.

However, saponins also demonstrate unfavorable side effects when consumed, and so careful strategies are needed to create compounds for clinical use. Problems associated with the low oral bioavailability of saponins need to be eliminated. Another important issue is to reduce or completely eliminate the hemolytic activity of saponins intended for use as anticoagulants.

The ability of saponins to increase membrane permeabilization is also an important issue. On the one hand, it can increase the bioavailability of drugs or vitamins, and on the other hand, it may lead to pro-thrombotic activity. This is especially important in the prothrombin activation process in which vitamin $\mathrm{K}$ serves as an essential effector for $\gamma$-glutamyl carboxylase, an enzyme that catalyzes the carboxylation of glutamic acid residues in prothrombin. Saponins are substances that increase the permeabilization of the microsomal membrane in this process and thus facilitate the coagulation [82-84]. 
Due to the lack of knowledge of their properties and their complex chemical composition, plants do not appear completely suitable for use in modern medicine. For example, different notoginsenosides isolated from the same plant of the genus Panax demonstrate quite different anticoagulant effects. Therefore, the best course of action may lie in the organic synthesis of new saponins, preceded by in silico analyses and modeling. Based on the already available knowledge about the influence of the chemical structure of saponins on their biological properties, one can strive to create appropriate compounds which are both non-toxic yet pharmacologically effective.

Funding: This research received no external funding.

Conflicts of Interest: The authors report no conflict of interest.

\section{References}

1. Chanda, S.; Ramachandra, T.V. A review on some therapeutic aspects of phytochemicals present in medicinal plants. IJPLS 2019, 10, 6064-6067.

2. El Aziz, M.M.A.; Ashour, A.S.; Melad, A.S.G. A review on saponins from medicinal plants: Chemistry, isolation, and determination. J. Nanomed. Res. 2019, 8, 6-12.

3. Xu, C.; Wang, W.; Wang, B.; Zhang, T.; Cui, X.; Pu, Y.; Li, N. Analytical methods and biological activities of Panax notoginseng saponins: Recent trends. J. Ethnopharmacol. 2019, 236, 443-465. [CrossRef] [PubMed]

4. Shi, Z.Y.; Zeng, J.Z.; Wong, A.S.T. Chemical structures and pharmacological profiles of ginseng saponins. Molecules 2019, 24, 2443. [CrossRef]

5. Yang, Y.; Laval, S.; Yu, B. Chemical synthesis of saponins. In Advances in Carbohydrate Chemistry and Biochemistry; Horton, D., Ed.; Academic Press: London, UK, 2014; Volume 77, pp. 137-226.

6. Cárdenas, P.D.; Almeida, A.; Bak, S. Evolution of structural diversity of triterpenoids. Front. Plant Sci. 2019, 10, 1-10. [CrossRef] [PubMed]

7. He, Y.; Hu, Z.; Li, A.; Zhu, Z.; Yang, N.; Ying, Z.; He, J.; Wang, C.; Yin, S.; Cheng, S. Recent advances in biotransformation of saponins. Molecules 2019, 24, 2365. [CrossRef] [PubMed]

8. Das, T.K.; Banerjee, D.; Chakraborty, D.; Pakhira, M.C.; Shrivastava, B.; Kuhad, R.C. Saponin: Role in animal system. Vet. World 2012, 5, 248-254. [CrossRef]

9. El Barky, A.R.; Hussein, S.A.; Alm-Eldeen, A.E. Saponins and their potential role in diabetes mellitus. Diabetes Manag. 2017, 7, 148-158.

10. Liu, Y.; Liu, T.; Zhao, J.; He, T.; Chen, H.; Wang, J.; Zhang, W.; Ma, W.; Fan, Y.; Song, X. Phospholipase C 22 signalling contributes to the haemostatic effect of Notoginsenoside Ft1. J. Pharm. Pharmacol. 2019, 71, 878-886. [CrossRef]

11. Xiong, Y.; Chen, L.; Man, J.; Hu, Y.; Cui, X. Chemical and bioactive comparison of Panax notoginseng root and rhizome in raw and steamed forms. J. Ginseng Res. 2019, 43, 385-393. [CrossRef] [PubMed]

12. Wu, Z.; Zhao, X.; Miyamoto, A.; Zhao, S.; Liu, C.; Zheng, W.; Wang, H. Effects of steroidal saponins extract from Ophiopogon japonicus root ameliorates doxorubicin-induced chronic heart failure by inhibiting oxidative stress and inflammatory response. Pharm. Biol. 2019, 57, 176-183. [CrossRef]

13. Sun, J.; Yu, X.; Huangpu, H.; Yao, F. Ginsenoside Rb3 protects cardiomyocytes against hypoxia/reoxygenation injury via activating the antioxidation signaling pathway of PERK/Nrf2/HMOX1. Biomed. Pharmacother. 2019, 109, 254-261. [CrossRef]

14. Dong, Y.; Duan, L.; Chen, H.-W.; Liu, Y.-M.; Zhang, Y.; Wang, J. Network Pharmacology-Based Prediction and Verification of the Targets and Mechanism for Panax Notoginseng Saponins against Coronary Heart Disease. Evidence-Based Complement. Altern. Med. 2019, 2019, 6503752. [CrossRef]

15. Evangelista, M.S.; Slompo, K.; Timi, J.R.R. Venous thromboembolism and route of delivery-Review of the literature. Rev. Bras. Ginecol. Obstet. 2018, 40, 156-162. [CrossRef]

16. Donnellan, E.; Khorana, A.A. Cancer and venous thromboembolic disease: A review. Oncologist 2017, 22, 199-207. [CrossRef]

17. Hirsch, E.G.; Viecili, P.R.N.; de Almeida, A.S.; Nascimento, S.; Porto, F.G.; Otero, J.; Schmidt, A.; de Silva, B.; Parisi, M.M.; Klafke, J.Z. Natural products with antiplatelet action. Curr. Pharm. Des. 2017, 23, 1228-1246. [CrossRef] [PubMed] 
18. Ouyang, X.L.; Mao, W.H.; Wang, C.G.; Pan, Y.M.; Liang, D.; Wang, H.S. Five $11 \alpha, 12 \alpha$-epoxy pentacyclic triterpenoid saponins with antithrombus activities from Glechoma longituba. Fitoterapia 2019, 138, 104345. [CrossRef] [PubMed]

19. Jin, X.; Luo, Y.; Chen, Y.; Ma, Y.; Yue, P.; Yang, M. Novel breviscapine nanocrystals modified by Panax notoginseng saponins for enhancing bioavailability and synergistic anti-platelet aggregation effect. Colloids Surf. B Biointerfaces 2019, 175, 333-342. [CrossRef] [PubMed]

20. Kim, K.; Park, K.I. A review of antiplatelet activity of traditional medicinal herbs on integrative medicine studies. Evid. Based Complement. Alternat. Med. 2019, 2019, 7125162. [CrossRef]

21. Cong, Y.; Wang, L.; Peng, R.; Zhao, Y.; Bai, F.; Yang, C.; Liu, X.; Wang, D.; Ma, B.; Cong, Y. Timosaponin AIII induces antiplatelet and antithrombotic activity via Gq-mediated signaling by the thromboxane A2 receptor. Sci. Rep. 2016, 6, 38757. [CrossRef]

22. Qi, H.; Huang, Y.; Yang, Y.; Dou, G.; Wan, F.; Zhang, W.; Yang, H.; Wang, L.; Wu, C.; Li, L. Anti-platelet activity of panaxatriol saponins is mediated by suppression of intracellular calcium mobilization and ERK2/p38 activation. BMC Complement. Altern. Med. 2016, 16, 1-8. [CrossRef] [PubMed]

23. Peng, Y.; Li, S.N.; Pei, X.; Hao, K. The multivariate regression statistics strategy to investigate content-effect correlation of multiple components in traditional Chinese medicine based on a partial least squares method. Molecules 2018, 23, 545. [CrossRef]

24. Kang, L.; Zhang, J.; Cong, Y.; Li, B.; Xiong, C.Q.; Zhao, Y.; Tan, D.W.; Yu, H.S.; Yu, Z.Y.; Cong, W.Y.; et al. Steroidal glycosides from the rhizomes of Anemarrhena asphodeloides and their antiplatelet aggregation activity. Planta Med. 2012, 78, 611-616. [CrossRef]

25. Zhai, K.F.; Zheng, J.R.; Tang, Y.M.; Li, F.; Lv, Y.N.; Zhang, Y.Y.; Gao, Z.; Qi, J.; Yu, B.Y.; Kou, J.P. The saponin D39 blocks dissociation of non-muscular myosin heavy chain IIA from TNF receptor 2, suppressing tissue factor expression and venous thrombosis. Br. J. Pharmacol. 2017, 174, 2818-2831. [CrossRef]

26. Li, H.; Huang, W.; Wen, Y.; Gong, G.; Zhao, Q.; Yu, G. Anti-thrombotic activity and chemical characterization of steroidal saponins from Dioscorea zingiberensis CH Wright. Fitoterapia 2010, 81, 1147-1156. [CrossRef]

27. Zhang, R.; Huang, B.; Du, D.; Guo, X.; Xin, G.; Xing, Z.; Liang, Y.; Chen, Y.; Chen, Q.; He, Y.; et al. Anti-thrombosis effect of diosgenyl saponins in vitro and in vivo. Steroids 2013, 78, 1064-1070. [CrossRef]

28. Lu, W.Q.; Qiu, Y.; Li, T.J.; Tao, X.; Sun, L.N.; Chen, W.S. Antiplatelet and antithrombotic activities of timosaponin B-II, an extract of Anemarrhena asphodeloides. Clin. Exp. Pharmacol. Physiol. 2011, 38, 430-434. [CrossRef]

29. Zhou, Z.; Wei, X.; Fu, H.; Luo, Y. Chemical constituents of Callicarpa nudiflora and their anti-platelet aggregation activity. Fitoterapia 2013, 88, 91-95. [CrossRef]

30. Dahmer, T.; Berger, M.; Barlette, A.G.; Reck, J.; Segalin, J.; Verza, S.; Ortega, G.G.; Gnoatto, S.C.; Guimarães, J.A.; Verli, H.; et al. Antithrombotic effect of chikusetsusaponin IVa isolated from Ilex paraguariensis (Mate). J. Med. Food. 2012, 15, 1073-1080. [CrossRef]

31. Lee, W.M.; Kim, S.D.; Park, M.H.; Cho, J.Y.; Park, H.J.; Seo, G.S.; Rhee, M.H. Inhibitory mechanisms of dihydroginsenoside Rg3 in platelet aggregation: Critical roles of ERK2 and cAMP. J. Pharm. Pharmacol. 2008, 60, 1531-1536. [CrossRef]

32. Zhang, Y.; Ma, X.J.; Shi, D.Z. Antiplatelet effect of active components derived from Chinese herbal medicine. Chin. J. Integr. Med. 2018, 24, 632-640. [CrossRef] [PubMed]

33. Lee, J.G.; Lee, Y.Y.; Kim, S.Y.; Pyo, J.S.; Yun-Choi, H.S.; Park, J.H. Platelet antiaggregating activity of ginsenosides isolated from processed ginseng. Die Pharm. 2009, 64, 602-604.

34. Li, C.T.; Wang, H.B.; Xu, B.J. A comparative study on anticoagulant activities of three Chinese herbal medicines from the genus Panax and anticoagulant activities of ginsenosides Rg1 and Rg2. Pharm. Biol. 2013, 51, 1077-1080. [CrossRef]

35. Shin, J.H.; Kwon, H.W.; Cho, H.J.; Rhee, M.H.; Park, H.J. Vasodilator-stimulated phosphoprotein-phosphorylation by ginsenoside Ro inhibits fibrinogen binding to $\alpha \mathrm{IIb} / \beta 3$ in thrombin-induced human platelets. J. Ginseng Res. 2016, 40, 359-365. [CrossRef]

36. Endale, M.; Lee, W.M.; Kamruzzaman, S.M.; Kim, S.D.; Park, J.Y.; Park, M.H.; Park, H.J.; Cho, J.Y.; Rhee, M.H. Ginsenoside-Rp1 inhibits platelet activation and thrombus formation via impaired glycoprotein VI signalling pathway, tyrosine phosphorylation and MAPK activation. Br. J. Pharmacol. 2012, 167, 109-127. 
37. Irfan, M.; Jeong, D.; Kwon, H.W.; Shin, J.H.; Park, S.J.; Kwak, D.; Kim, T.H.; Lee, D.H.; Park, H.J.; Rhee, M.H. Ginsenoside-Rp3 inhibits platelet activation and thrombus formation by regulating MAPK and cyclic nucleotide signaling. Vascul. Pharmacol. 2018, 109, 45-55.

38. Son, Y.M.; Jeong, D.H.; Park, H.J.; Rhee, M.H. The inhibitory activity of ginsenoside Rp4 in adenosine diphosphate-induced platelet aggregation. J. Ginseng Res. 2017, 41, 96-102.

39. Kothiyal, S.K.; Sati, S.C.; Rawat, S.M.M.; Sati, M.D.; Semwal, D.K.; Semwal, R.B.; Sharma, A.; Rawat, B.; Kumar, A. Chemical constituents and biological significance of the genus Ilex (Aquifoliaceae). Nat. Prod. J. 2012, 2, 212-224.

40. Liu, Y.; Liu, T.; Ding, K.; Liu, Z.; Li, Y.; He, T.; Zhang, W.; Fan, Y.; Ma, W.; Song, X. Phospholipase C 2 signaling cascade contribution to the antiplatelet effect of Notoginsenoside Fc. Front. Pharmacol. 2018, 9, 1293. [CrossRef]

41. Huang, H.C.; Tsai, W.J.; Morris-Natschke, S.L.; Tokuda, H.; Lee, K.H.; Wu, Y.; Kuo, Y.H. Sapinmusaponins F- J, bioactive tirucallane-type saponins from the galls of Sapindus mukorossi. J. Nat. Prod. 2006, 69, 763-767. [CrossRef]

42. Huang, H.C.; Tsai, W.J.; Liaw, C.C.; Wu, S.H.; Wu, Y.C.; Kuo, Y.H. Anti-platelet aggregation triterpene saponins from the galls of Sapindus mukorossi. Chem. Pharm. Bull. 2007, 55, 1412-1415. [CrossRef] [PubMed]

43. Rao, G.H.R. Arachidonic acid metabolism, thrombosis, and stroke. J. Cardiol. Cardiovasc. Ther. 2018, 11, 1-3. [CrossRef]

44. Martin, S.A.; Brash, A.R.; Murphy, R.C. The discovery and early structural studies of arachidonic acid. J. Lipid Res. 2016, 57, 1126-1132. [CrossRef]

45. Biringer, R.G. The enzymes of the human eicosanoid pathway. Res. Rep. Med. Sci. 2018, 2, 106.

46. Hao, Y.; Tatonetti, N.P. Predicting G protein-coupled receptor downstream signaling by tissue expression. Bioinformatics 2016, 32, 3435-3443. [CrossRef]

47. Powell, W.S.; Rokach, J. Biosynthesis, biological effects, and receptors of hydroxyeicosatetraenoic acids (HETEs) and oxoeicosatetraenoic acids (oxo-ETEs) derived from arachidonic acid. Biochim. Biophys. Acta 2015, 1851, 340-355. [CrossRef] [PubMed]

48. Ju, H.K.; Lee, J.G.; Park, M.K.; Park, S.J.; Lee, C.H.; Park, J.H.; Kwon, S.W. Metabolomic investigation of the anti-platelet aggregation activity of ginsenoside Rk1 reveals attenuated 12-HETE production. J. Proteome Res. 2012, 11, 4939-4946. [CrossRef]

49. Dütting, S.; Bender, M.; Nieswandt, B. Platelet GPVI: A target for antithrombotic therapy?! Trends Pharmacol. Sci. 2012, 33, 583-590. [CrossRef]

50. Adam, F.; Kauskot, A.; Rosa, J.P.; Bryckaert, M. Mitogen-activated protein kinases in hemostasis and thrombosis. J. Thromb. Haemost. 2008, 6, 2007-2016. [CrossRef]

51. Adam, F.; Kauskot, A.; Nurden, P.; Sulpice, E.; Hoylaerts, M.F.; Davis, R.J.; Rosa, J.P.; Bryckaert, M. Platelet JNK1 is involved in secretion and thrombus formation. Blood 2010, 115, 4083-4092. [CrossRef]

52. Makhoul, S.; Walter, E.; Pagel, O.; Walter, U.; Sickmann, A.; Gambaryan, S.; Smolenski, A.; Zahedi, R.P.; Jurk, K. Effects of the NO/soluble guanylate cyclase/cGMP system on the functions of human platelets. Nitric Oxide 2018, 76, 71-80. [CrossRef]

53. Shin, J.H.; Kwon, H.W.; Rhee, M.H.; Park, H.J. Inhibitory effects of thromboxane A2 generation by ginsenoside Ro due to attenuation of cytosolic phospholipase A2 phosphorylation and arachidonic acid release. J. Ginseng Res. 2019, 43, 236-241. [CrossRef] [PubMed]

54. Thibeault, P.E.; Ramachrandran, R. Biased signalling in platelet G-protein-coupled receptors. Can. J. Physiol. Pharmacol. 2020. [CrossRef]

55. Offermanns, S. Activation of platelet function through G protein-coupled receptors. Circ. Res. 2006, 12, 1293-1304. [CrossRef]

56. Grover, S.P.; Mackman, N. Tissue factor: An essential mediator of hemostasis and trigger of thrombosis. Arterioscler. Thromb. Vasc. Biol. 2018, 38, 709-725. [CrossRef] [PubMed]

57. Brummel-Ziedins, K.; Mann, K.G. Molecular basis of blood coagulation. In Hematology, 6th ed.; Shaz, B., Hilley, C., Gil, M., Eds.; Elsevier Saunders: Philadelphia, PA, USA, 2018; pp. 1885-1905.

58. Gil, M.R. Overview of the coagulation system. In Transfusion Medicine and Hemostasis; Shaz, B., Hilley, C., Gil, M., Eds.; Elsevier Saunders: Philadelphia, PA, USA, 2019; pp. 559-564.

59. Hoffman, M. The tissue factor pathway and wound healing. Semin. Thromb. Hemost. 2018, 44, 142-150. [CrossRef] [PubMed] 
60. Zhai, K.; Tang, Y.; Zhang, Y.; Li, F.; Wang, Y.; Cao, Z.; Yu, J.; Kou, J.; Yu, B. NMMHC IIA inhibition impedes tissue factor expression and venous thrombosis via Akt/GSK3beta-NF-kappa B signalling pathways in the endothelium. Thromb. Haemost. 2015, 114, 173-185. [CrossRef]

61. Zhang, Y.; Li, L.; Zhao, Y.; Han, H.; Hu, Y.; Liang, D.; Yu, B.; Kou, J. The myosin II inhibitor, blebbistatin, ameliorates FeCl3-induced arterial thrombosis via the GSK3 $\beta-N F-k B$ pathway. Int. J. Biol. Sci. 2017, 13, 630-639. [CrossRef]

62. Singh, D.; Chaudhuri, P.K. Structural characteristics, bioavailability and cardioprotective potential of saponins. Integr. Med. Res. 2018, 7, 33-43. [CrossRef]

63. DrugBank Database. Available online: https://www.drugbank.ca/ (accessed on 9 January 2020).

64. Tian, Z.; Pang, H.; Du, S.; Lu, Y.; Zhang, L.; Wu, H.; Guo, S.; Wang, M.; Zhang, Q. Effect of Panax notoginseng saponins on the pharmacokinetics of aspirin in rats. J. Chromatogr. B 2017, 1040, 136-143. [CrossRef]

65. Tian, Z.; Pang, H.; Zhang, Q.; Du, S.; Lu, Y.; Zhang, L.; Bai, J.; Li, P.; Zhao, M.; Chen, X. Effect of aspirin on the pharmacokinetics and absorption of Panax notoginseng saponins. J. Chromatogr. B 2018, 1074, 25-33. [CrossRef]

66. Leon, M.; Johanna, M. The synopsis of biological and pharmacological events in saponins. IJLES 2018, 1, 1-5.

67. Zhang, X.; Jin, M.; Tadesse, N.; Xian, L.; Zhang, H.; Wang, S.; Dang, J.; Zhang, Y.; Guo, Z.; Ito, Y. Safety investigation on total steroid saponins extracts from Dioscorea zingiberensis CH Wright: Sub-acute and chronic toxicity studies on dogs. Regul. Toxicol. Pharmacol. 2017, 91, 58-67. [CrossRef]

68. Abou-Hashem, A.A.M. Evaluation of the rodenticidal effects of some plant extracts under laboratory and field conditions. J. Basic Appl. Zool. 2012, 65, 282-288. [CrossRef]

69. Hansen, S.C.; Stolter, C.; Imholt, C.; Jacob, J. Plant secondary metabolites as rodent repellents: A systematic review. J. Chem. Ecol. 2016, 42, 970-983. [CrossRef]

70. Abu, O.D.; Adeogun, E.F.; Ebhohon, S.O. Oral LD50 of total saponins and tannins isolated from Dialium guineense. Eur. J. Exp. Biol. 2019, 9, 11-13.

71. Alias, E.; Zeinelabdin, M.; Bashir, N.; Assad, Y. Acute toxicity of saponins from the fruit of bitter apple Citrullus colocynthis (L.) Schrad, on the Norway rat, Rattus norvegicus (Berkenhout). Gezira J. Agric. Sci. 2015, $13,1$.

72. Shu, Y.; Cao, M.; Yin, Z.Q.; Li, P.; Li, T.Q.; Long, X.F.; Zhu, L.F.; Jia, R.Y.; Dai, S.J.; Zhao, J. The reproductive toxicity of saponins isolated from Cortex Albiziae in female mice. Chin. J. Nat. Med. 2015, 13, 119-126. [CrossRef]

73. Zheng, S.; Wang, Y.; Liu, H.; Chang, W.; Xu, Y.; Lin, F. Prediction of hemolytic toxicity for saponins by machine-learning methods. Chem. Res. Toxicol. 2019, 32, 1014-1026. [CrossRef]

74. Lorent, J.H.; Quetin-Leclercq, J.; Mingeot-Leclercq, M.P. The amphiphilic nature of saponins and their effects on artificial and biological membranes and potential consequences for red blood and cancer cells. Org. Biomol. Chem. 2014, 12, 8803-8822. [CrossRef] [PubMed]

75. de Groot, C.; Müller-Goymann, C.C. Saponin interactions with model membrane systems-Langmuir monolayer studies, hemolysis and formation of ISCOMs. Planta Med. 2016, 82, 1496-1512. [CrossRef]

76. Sarikahya, N.B.; Nalbantsoy, A.; Top, H.; Gokturk, R.S.; Sumbul, H.; Kirmizigul, S. Immunomodulatory, hemolytic and cytotoxic activity potentials of triterpenoid saponins from eight Cephalaria species. Phytomedicine 2018, 38, 135-144. [CrossRef]

77. Vo, N.N.Q.; Fukushima, E.O.; Muranaka, T. Structure and hemolytic activity relationships of triterpenoid saponins and sapogenins. J. Nat. Med. 2017, 71, 50-58. [CrossRef] [PubMed]

78. Xiao, G.; Shao, X.; Zhu, D.; Yu, B. Chemical synthesis of marine saponins. Nat. Prod. Rep. 2019, 36, 769-787. [CrossRef]

79. Zhang, X.J.; Su, H.; Wang, Y.T.; Wan, J.B. Therapeutic potential of ginsenosides in management of atherosclerosis. In Phytotherapies: Efficacy, Safety, and Regulation; Ramzon, I., Ed.; John Wiley and Sons, Inc.: Hoboken, NJ, USA, 2015.

80. Liu, C.; Feng, R.; Zou, J.; Xia, F.; Wan, J.B. 20(S)-protopanaxadiol saponins mainly contribute to the anti-atherogenic effects of Panax notoginseng in ApoE deficient mice. Molecules 2019, 24, 3723. [CrossRef]

81. Laine, M.; Paganelli, F.; Bonello, L. P2Y12-ADP receptor antagonists: Days of future and past. World J. Cardiol. 2016, 8, 327-332. [CrossRef]

82. Ayombil, F.; Camire, R.M. Insights into vitamin K-dependent carboxylation: Home field advantage. Haematologica 2020, 105, 1996-1998. [CrossRef] [PubMed] 
83. Sun, F.; Ye, C.; Thanki, K.; Leng, D.; van Hasselt, P.M.; Hennink, W.E.; van Nostrum, C.F. Mixed micellar system stabilized with saponins for oral delivery of vitamin K. Colloids Surf. B Biointerfaces 2018, 170, 521-528. [CrossRef]

84. Tollefsen, S.; Wierød, L.; Skotte, A.; Rob, J.A.; Helgeland, L. Saponin permeabilization of rough microsomes from rat liver reveals a novel prothrombin pool. Biochim. Biophys. Acta 2001, 1526, 249-256. [CrossRef]

Publisher's Note: MDPI stays neutral with regard to jurisdictional claims in published maps and institutional affiliations.

(C) 2020 by the authors. Licensee MDPI, Basel, Switzerland. This article is an open access article distributed under the terms and conditions of the Creative Commons Attribution (CC BY) license (http://creativecommons.org/licenses/by/4.0/). 